\title{
CRIMINAL OFFENSES - A NEW INSTITUTE OF CRIMINAL LEGISLATION OF UKRAINE
}

\author{
S.S. KOVALOVA, Candidate of Law, \\ Senior Lecturer of the Department of Administrative and Financial Law, \\ National University of Life and Environmental Sciences of Ukraine \\ E-mail: kovalyeva@gmail.com
}

Summary. The article analyzes the feasibility of introducing the institution of criminal offense. The focus is on reforming the criminal justice system.

It was found out that one of the directions of reforming the criminal justice of Ukraine is the introduction of the institute of criminal misdemeanor in the criminal legislation.

According to the results of the study, different approaches to the expediency of establishing liability for misconduct in the criminal legislation of Ukraine have been identified.

It is reasonable that changing the understanding of the concept of crime and the criteria for its evaluation is not an easy path, but in today's conditions the introduction of criminal offenses is a progressive, timely and unalterable step, as no scientific developments can solve law enforcement problems.

Keywords: criminal proceedings, institute of criminal offense, crime, reforming, criminal legislation, Concept of reforms, criminal justice

\section{Introduction.}

Radical changes in the socio-political living conditions of the state have created the preconditions for reforming the criminal justice system in the direction of further humanization, democratization and strengthening the protection of human rights and freedoms. One of the directions of reforming the criminal justice of Ukraine is the introduction of criminal misconduct in criminal law.

The purpose of the article is to study the normative consolidation of the institution of criminal offense on the basis of the current state of the Criminal Code of Ukraine.

\section{Analysis of recent researches and publications.}

This issue has been studied by such scientists as V.I Borisov, N.D. Kuznetsov. V.M. Kutz, A.A. Music, A.S. Politova, V.Y. Tatsiy, M.I. Havronuk P.L. Fries, B.W. Shuba and others.

\section{Results.}

The priority component of the process of Ukraine's integration into the European Union is the fulfillment of the third Copenhagen and Madrid criteria, ie the adaptation of national legislation to the EU le- 
gal system. One of the areas of adaptation is the humanization of criminal liability (Chernychenko, 2016: 320-323).

In pursuance of the above requirements, the Concept of Criminal Justice Reform of Ukraine was developed with the participation of international experts and civil society representatives.

Accordingly, the Concept defines the content and directions of reforming the criminal justice system, in particular:

- humanization of criminal law;

- restructuring of the organizational and functional structure of criminal justice in accordance with the norms of the reformed legislation;

- strengthening the protection of the rights and interests of victims, guaranteed compensation for damage caused by the crime;

- expanding the use of restorative procedures and reconciliation.

In order to implement the provisions of the Concept of Criminal Justice Reform of Ukraine, a new Criminal Procedure Code of Ukraine was adopted, which entered into force on November 20, 2012. The adoption of the Criminal Procedure Code marked the beginning of a new stage in the development of criminal procedure legislation. Along with the emergence of new legal provisions in the $\mathrm{CPC}$, it reflected the institution of criminal offenses. However, for many years the code remained the only piece of legislation that contained provisions on criminal offenses. It is these norms that have become the catalyst for lively discussions in numerous expert groups, conferences and other scientific events.

Referring to the history of the institution of criminal misconduct, it should be noted that the division of criminally punishable acts into crimes and misdemeanors has been known to the legislation of the Russian Empire since its adoption in 1845. Penal Code. Only a corrective punishment is imposed for misdemeanors. The separation of criminal offenses into a separate type of criminally punishable acts was also preserved in the Criminal Code of 1903 (Politova, 2013: 71-77).

According to this legal act, they were punished by arrest or a fine. As for the legislation during the Soviet era, neither the Criminal Code of Ukraine nor the Criminal Code of other Soviet republics followed the path of criminal offenses as an independent institution of criminal law, although the science of criminal law in the 60 s of the last century minor gravity in the category of anti-social misconduct (Chernychenko, 2016: 320-323). PL Fries defines that «there are several options for the definition of this new institution: criminal offenses, criminal offenses, offenses», and proposes to use the term «criminal offenses» (Fris, 2011: 43-44). The term «criminal offense» is used by V.O. Tulyakov (Tuliakov V.A., 2011:23-25). The concept of misconduct is also found in administrative law. According to Art. 9 of the Code of Ukraine on Administrative Offenses (hereinafter - KUpAP) «Administrative offense (misdemeanor) is an illegal, guilty (intentional or negligent) act or omission that encroaches on public order, property, rights and freedoms of citizens, the established order of management and for which the legislation provides for administrative liability».

The expediency of the introduction of criminal offenses is also evidenced by foreign experience: the criminal law of the vast majority of European countries and other countries provides for two or even three types of criminal acts, namely: crime-misdemeanor-violation, and in the Anglo-Saxon legal family felony and misdemeanor. In Europe, it

140 | ISSN 2663-1350 «ПРАВО. ЛЮДИНА. ДОВКІЛЛЯ»| «LAW. HUMAN. ENVIRONMENT» Vol. 11, № 4, 2020 
has long been concluded that in the field of criminal law there can be only one type of punishable acts (crime) - and not only by their severity, but also by the degree of punishment and legal consequences for the convicted person, the order of investigation and trial.

Of course, in our opinion, the institution of criminal offenses should be introduced directly with the adoption of the new CCP. However, this required a radical overhaul of the concept of constructing substantive law.

On July 1, 2020, the amendments to the current Criminal Code approved by the Verkhovna Rada of Ukraine came into force, which made it possible to earn the institute of criminal offenses. The relevant changes are intended to simplify the procedure for investigating minor offenses.

Under the new law, a criminal offense is one of the types of criminal offense (the second is a crime), for the commission of which criminal liability is provided. It is proposed to recognize an act (action or omission) as a criminal offense, for the commission of which the main punishment in the form of a fine of not more than 51 thousand UAH. or other punishment not related to imprisonment. Interestingly, a person will not be prosecuted for preparing to commit a criminal offense (unlike a crime). Analysis of the proposed amendments to the Criminal Code of Ukraine allows us to note that the legislator simply transferred minor crimes into the category of misdemeanors, justifying the possibility and expediency of such a division on the basis of a much lower degree of public danger of minor crimes compared to medium, serious and especially serious crimes. In fact, the need for separation was laid down during the adoption of the new Criminal Procedure Code.
A similar division of offenses into crimes and criminal offenses exists in many countries, including Estonia, Latvia, Switzerland, Hungary, and Turkey.

Regarding the legality of the introduction of the category "criminal offense» and its types, it should be noted that in accordance with the provisions of Part 2 of Article 1 of the Criminal Code only the Criminal Code determines which socially dangerous acts are crimes and what punishment is applied to those who committed them. Therefore, in our opinion, the introduction of the concept of «criminal offense» without making appropriate changes to the law on criminal liability is not entirely justified, but at the same time a forced step given a number of decisions of the European Court of Human Rights in Ukraine. However, it should be noted that the main reason for the changes is reflected in the title itself: the Law «On Amendments to Certain Legislative Acts of Ukraine Concerning the Simplification of Pre-trial Investigation of Certain Categories of Criminal Offenses».

At the same time, the legislator rightly believes that a simplified procedure for pre-trial investigation in the form of investigation of all minor criminal offenses will help reduce the burden on the pre-trial investigation. Under the new law, they will investigate misdemeanors under an abbreviated procedure in the form of a pre-trial inquiry, the duration of which will not exceed 1 month from the date of service of the notice of suspicion.

The inquiry will be carried out by investigators - police officers, authorized persons of the Security Service, bodies that monitor compliance with tax legislation, representatives of the State Bureau of Investigation, the State Penitentiary Service of Ukraine and the National Anti-Corruption Bureau. 
Due to the much lower degree of public danger, restrictions on the rights of suspects will apply in exceptional cases.

Such a radical measure as the detention of a suspect in a criminal offense for one day can be applied if the person is intoxicated and his actions pose a danger to others.

But you can be detained for 72 hours if the violator, in response to the request of the police to stop the illegal behavior, resists or continues to commit a misdemeanor, or tries to escape.

After serving the sentence, a person who has been prosecuted for a criminal offense will be considered not to have a criminal record.

Among the approved changes, which came into force on July 1, 2020, are the following:

- according to the accepted changes in Art. 12 of the Criminal Code of Ukraine criminal offenses are divided into criminal offenses and crimes;

A criminal offense is an act (action or omission) provided by the Criminal Code, for which the main punishment is a fine of not more than three thousand non-taxable minimum incomes or other punishment not related to imprisonment.

Accordingly, crimes are divided into minor, serious and especially serious.

- in Art. 14 of the Criminal Code of Ukraine stipulates that preparation for a criminal offense does not entail criminal liability;

- according to Art. 21 of the Criminal Code of Ukraine are subject to criminal liability of persons who have committed criminal offenses in a state of alcohol, drugs or other intoxication or under the influence of drugs that reduce attention and speed of reaction;

- in Art. 45-49 of the Criminal Code of Ukraine provides the grounds and conditions for release from criminal liability of a person who has committed a criminal offense;

- in accordance with Art. 74 of the Criminal Code of Ukraine, a person who has committed a criminal offense or a minor crime, in addition to corruption offenses, may be released from punishment by a court sentence;

- parole is provided for serving a sentence for a criminal offense (Article 81 of the Criminal Code of Ukraine) and replacing the unserved part of the sentence with a milder one (Article 82 of the Criminal Code of Ukraine).

- in Art. 74 of the Criminal Code of Ukraine states that persons convicted of a criminal offense, after serving the sentence, are recognized as having no criminal record.

- Exemption from criminal liability with the application of coercive measures of an educational nature to a minor who first committed a criminal offense (Articles 97, 105 of the Criminal Code of Ukraine) and exemption from criminal liability and serving a sentence in connection with the expiration of the statute of limitations Of Ukraine.

Analysis of the current criminal code gives grounds to note that criminal offenses include such common crimes as:

- theft (Part 1 of Article 185 of the Criminal Code of Ukraine);

- fraud (Part 1 of Article 190 of the Criminal Code of Ukraine);

- illegal hunting (Part 1 of Article 248 of the Criminal Code of Ukraine) illegal occupation by fish, animal or other water extractive industry (part 1 of Article 249 of the Criminal Code of Ukraine);

- violation of the requirements of the legislation on labor protection (part 1 of Article 271 of the Criminal Code of Ukraine); 
- violation of safety rules during the performance of high-risk work (Part 1 of Article 272 of the Criminal Code of Ukraine);

- violation of air flight rules (Part 1 of Article 281 of the Criminal Code of Ukraine) and violation of the rules of use of airspace (Part 1 of Article 282 of the Criminal Code of Ukraine);

- group violation of public order (Article 293 of the Criminal Code of Ukraine);

- hooliganism (Article 296 of the Criminal Code of Ukraine);

- cruel treatment of animals (Article 299 of the Criminal Code of Ukraine);

- creation or maintenance of places of debauchery and pimping (Part 1 of Article 302 of the Criminal Code of Ukraine);

- illegal production, manufacture, purchase, storage, transportation or shipment of narcotic drugs, psychotropic substances or their analogues without the purpose of sale (Part 1 of Article 309 of the Criminal Code of Ukraine);

- resistance to a government official, law enforcement officer, state executor, private executor, member of a public formation for protection of public order and state border or servicemen, authorized person of the Deposit Guarantee Fund of individuals (Part 1 of Article 342 of the Criminal Code of Ukraine).

In addition, the Criminal Code is supplemented by Article 286-1, which provides for a sanction for driving under the influence of alcohol, drugs or other intoxicants or under the influence of drugs that reduce their attention and speed of reaction, as well as the transfer of control to a person who is in a state of intoxication or under the influence of such drugs in the form of a fine of one thousand to two thousand non-taxable minimum incomes, with deprivation of the right to drive for up to three years.

\section{Conclusions and prospects.}

According to experts, the introduced changes will not ensure the implementation of one of the main tasks of modern criminal law policy. The current Criminal Code of Ukraine is not able to fully perform the tasks assigned to it.

At present, the path chosen today does not solve the problem of administrative torts with judicial jurisdiction, which, according to scholars, are closer to the category of criminal offenses (Politova, 2013: 71-77), In view of the above, it can be stated that both in science and and in practice, the application of criminal law on the introduction of the institution of criminal offense continues an active discussion. On the one hand, the introduced novella will simplify the process of qualification of criminal offenses, provide organizational and procedural simplifications when considering materials of criminal proceedings, and on the other hand - arguments of scientists and practitioners critical of such changes are also substantiated and seem quite valid. That is why some scholars suggest concentrating misdemeanors in a separate normative act: the Code of Criminal Offenses (Politova, 2013: 71-77).

However, we are convinced that the introduction of the institution of criminal offenses in the legislation of our state is a progressive and timely step.

Of course, changing the theoretical foundations of understanding the crime and the criteria for its evaluation is not an easy path, but in today's conditions the introduction of criminal offenses is an unalterable step, as no scientific developments and discussions, unfortunately, can solve the problem of law enforcement. 


\section{References}

1. Chernychenko, V.I. (2016). Vhrovadzhennia instytutu kriminalnykh prostuprivv Ukraini. Chasopys Kyivskoho universytetu prava, 4: 320-323 (in Ukrainian).

2. Politova, A.S. (2013). Kriminalnyi prostupok yak novella reformuvannia kryminalnoi yustytsi. Visnyk Kryminolohichnoi asotsiatsii Ukrainy, 4: 71-77 (in Ukrainian).

3. Fris, P. (2011). Zlochyn i kryminalna provyna: problemy normatyvnoho zakriplennia. Pravo Ukrainy, 43-44 (in Ukrainian).

4. Tuliakov, V.A. (2011). Nekotorye voprosy sovremennoi uholovno-pravovoi doktryny. Naukovyi visnyk Mizhnarodnoho humanitarnoho universytetu, 1: 23-25 (in Russian).

5. Kodeks Ukrainy pro administratyvni pravoporushennia 07.12.1984. Vidomosti Verkhovnoi Rady URSR, dodatok № 51, 1122 (in Ukrainian).

6. Kryminalnyi kodeks Ukrainy 05.04.2001. Vidomosti Verkhovnoi Rady Ukrainy, 25-26, 131 (in Ukrainian).

\section{С.С. Ковальова (2020). КРИМІНАЛЬНІ ПРОСТУПКИ - НОВИЙ ІНСТИТУТУ КРИМІНАЛЬНОГО ЗАКОНОДАВСТВА УКРАЇНИ. ПравО. ЛюдИна. ДовКілЛЯ,} 11(4): 139-144. https://doi.org/10.31548/law2020.04.017.

Анотація. У статті проаналізовано доцільність впровадження інституту кримінального проступку. Зосереджено увагу на напрямках ресормування системи кримінальної юстичії.

3'ясовано, що одним із напрямків реформування кримінальної юстиції України є запровадження в кримінальне законодавство інституту кримінального проступку.

За результатами проведеного дослідження визначені різні підходи щодо питання доцільності встановлення відповідальності за проступок у кримінальному законодавстві України.

Обгрунтовно, що зміна розуміння поняття злочину та критеріїв його оцінки - щлях непростий, однак в умовах сьогодення запровадження інституту кримінальних проступків є кроком прогресивним, своєчасним та безальтернативним, оскільки жодні наукові розробки не спроможні розв'язати проблеми правозастосування.

Ключові слова: кримінальне провадження, інститут кримінального проступку, злочин, реформування, кримінальне законодавство, Концепція реформуванн, кримінальна юстиція 